\title{
温水循環加温システムを有する 排水性舗装橋梁道路中の熱・水分移動 HEAT AND MASS TRANSFER IN A DRAINAGE BRIDGE ROAD EQUIPPED WITH A HYDRONIC ROAD HEATING SYSTEM
}

\author{
藤本明宏 1 ・寺崎寛章 2 - HUMAYUN Md. Kabir ${ }^{3}$ ・福原輝幸 4 \\ Akihiro FUJIMOTO, Hiroaki TERASAKI, Kabir Md. HUMAYUN and Teruyuki FUKUHARA \\ 1正会員 工博 元福井大学大学院研究員（現土木研究所寒地土木研究所）（广910-8507 福井市文京3丁目9-1） \\ 2正会員 工博 福井大学特命助教 福井大学大学院工学研究科（干910-8507 福井市文京3丁目9-1） \\ ${ }^{3}$ Member of the Institution of Engineers, Bangladesh, Khulna University of Engineering \& Technology \\ (Khulna-9203, Bangladesh) \\ 4正会員 工博 福井大学教授 福井大学大学院工学研究科（干910-8507 福井市文京3丁目9-1）
}

\begin{abstract}
In order to better understand heat and mass transfer in drainage bridge road equipped with a hydronic road heating system (HRHS), a series of experiments were conducted using a test piece of a bridge road with the HRHS, a drainage pavement, and a rainfall simulator. Main experimental outputs are the hydraulic conductivity of the porous pavement, percolation velocity, vertical temperature profile in a bridge road and aggregate temperature associated with the heat injection from the HRHS and precipitation. It is concluded that (i) the proposed experimental method and Dupuit's approximations can be a good combination to identify the hydraulic conductivity and percolation performance, (ii) percolation velocity is more than 100 times larger than rainfall intensity, (iii) thermal interactions between aggregate, percolation fluid and void air should be considered to evaluate the performance of the HRHS as an antiicer or melting equipment.
\end{abstract}

Key Words : hydronic road heating system, drainage pavement, heat and mass transfer, hydraulic conductivity, percolation velocity

\section{1.はじめに}

密粒度舗装の湿潤路面では，ハイドロプレーニング現 象に加えて，凍結によるスリップ事故に注意を払う必要 がある．速やかに降雨や融雪水を浸透・排出させる排水 性舗装は，ハイドロプレーニング現象の防止に効果的で ある. その他に排水性舗装は，前方車両や対面車両の水 はねによるドライバーの視認性低下の抑止，粗な路面テ クスチャによるすべり摩擦係数の増大吕および車両通過 に伴う騒音低減の効果があり，2005年から積雪寒冷地を 含めて全国的に一般国道での施工が広がった. その施工

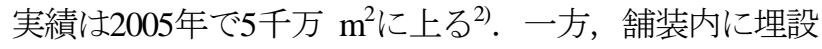
した熱交換パイプに温水を循環させることで路面を加温 する無散水融雪システム（以下，温水循環加温

(Hydronic Road Heating) システム, HRHS) は, 凍結 防止剤の削減, 路面の積雪や凍結の回避に有効な手段の
一つである. HRHS は，橋梁やトンネル坑口など局所的 な凍結や積雪の抑止策として導入されることが多く，地 中，地下水，河川水，川や湖沼の貯留水などの自然熱工 ネルギーを利用することで, 電気式ロードヒーティング と比較して安価なランニングコストが特徴の一つである. こうした HRHS の特徵や現状については参考文献3)を参 照されたい. 本研究では，HRHS を有する排水性舗装

(以下, HRHS drainage pavement, HRHS-DP) に着目し ているので，排水性舗装および HRHS-DP に関する既往 の研究を以下に述べる．積雪寒冷地における排水性舗装 の適用性に関する研究として，杉村4) は，排水性舗装の 路面温度が密粒度舗装のそれより低く, 路面凍結や路面 積雪が発生し易いことを観測した。早坂5)は，一般国道 39号線における野外観測より，降雪後の路面温度は排水 性舗装が密粒度舗装より低下し易いことを報告した。 日 本道路公団 $\left.{ }^{6}\right)$ は，排水性舗装は骨材間の空隙部に雪が詰 まるため，密粒度舗装より白く観えるが，そのすべり摩 


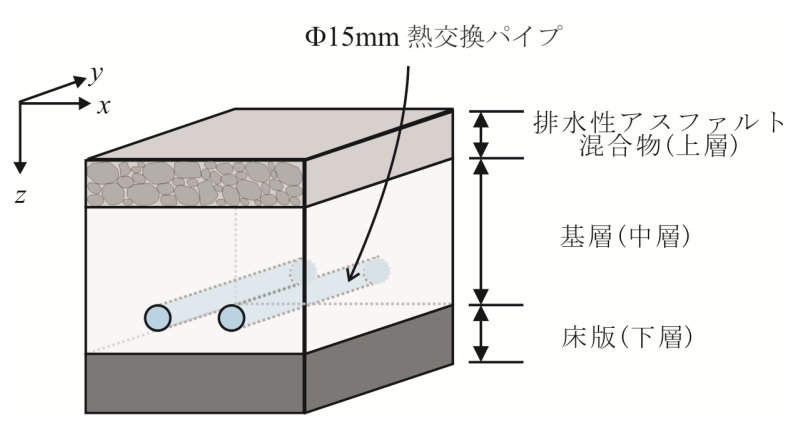

図-1 温水循環加温システムを組み入れた排水性舗装橋梁道 路の概要

擦係数は密粒度舗装に比べて高いことを報告した。また， 凍結防止剤の持続時間は両舗装で異なることも示した.

久保・寺田》は, 路面温度と塩濃度の関係が排水性舗装 と密粒度舗装で異なることを示した．また，同じ場所に 密粒度舗装と排水性舗装を敷設したとしても，降雪強度 によっては排水性舗装のみで積雪が発生した事例を紹介 した.

次に, HRHS-DPに関する研究について述べる. HRHS は，人口密度の高い降雪地带を数多く有する日本で先進 的に発展してきた技術であり，HRHS-DPに関する研究 は国外では見当たらない ${ }^{8}$. 藤森・佐野9 の底部に異なる断面を有したレール状の加工物を接着さ せ，その加工物の空隙に温水を通過させる新しい無散水 融雪システムを提案した．彼らは，実験から排水性舗装 上の積雪の融解時間と通水条件（流体温度と流量）の関 係を明らかにし，提案したシステムの有効性を証明した。 山口ら ${ }^{10} 1$ は，室内実験からHRHSの凍結防止・融雪性能 について, 密粒度舗装と排水性舗装で比較検証した。 そ の結果，凍結防止性能については両舗装に違いが無いが, 融雪性能については密粒度舗装に比べて排水性舗装は完 全融雪までに多くの時間を要することを明らかにした. このように既往の研究では，主に密粒度舗装と排水性舗 装との比較を通じてHRHS-DPの凍結防止・融雪性能を 定性的に検証するに留まっている.

HRHS-DP の舗装表面では，密粒度舗装と同様に気象 や交通の熱的影響, HRHS からの骨材や空隙を介した熱 供給および降雨や融水水に伴う熱損失が同時に作用する したがって, HRHS-DP の凍結防止・融雪性能を評価す るには, 舗装内の排水挙動およびそれに伴う浸透水や骨 材中の熱移動を明らかにする必要がある。また，HRHS の規模やコスト削減を行うためには, HRHS-DP の熱・ 水分移動モデルが不可欠となるが，上述したように理論 構築の根拠となる現象の解明は不十分である. 特に降雨 強度と排水性舖装内部の鉛直浸透速度との関係や，浸透 水と骨材を同じ温度と見做して扱って良いか，あるいは 個別に扱うべきかなど，モデル構成を決めるための知見 にそしい.

そこで本研究では理論モデル構築のために排水性アス
ファルト混合物の透水係数や鉛直浸透速度を求めるため の実験方法を提案すると共に, この種の研究では初めて となる骨材温度と排水温度の同時測定結果を示し, HRHS-DP の熱・水分移動特性を明らかにすることを目 的とする.

\section{HRHS を有する排水性舗装橋梁道路}

図-1は，HRHS を組み入れた排水性舗装橋梁道路の概 要を示す. 当道路は, 表層の排水性アスファルト混合物, 中層の基層および下層の床版で構成される. 排水性アス ファルト混合物は透水層である. 雨水や融雪水は，排水 性アスファルト混合物内を鉛直（z）方向に浸透してそ の底部に達した後, 基層上を主流 $(x)$ 方向に移動し, 下流端面から排出される. 基層および床版は不透水層で あり, 基層には道路を加温するための熱交換パイプ (heat exchange pipe, HEP) が埋設される.

\section{3. 室内実験}

本研究では，HRHS を組み入れた排水性舗装橋梁道路 の熱・水分移動を明らかにするために透水実験, 鉛直浸 透実験，降雨透水実験および熱・水分移動実験を実施し た．実験には全て同じ排水性アスファルト混合物を使用 し，その大きさは縦 $0.30 \mathrm{~m}$, 横 $0.30 \mathrm{~m}$ および高さ $0.03 \mathrm{~m}$ である. 骨材の最大粒径は $13 \mathrm{~mm}$, 平均粒径は7.5 mm, 間隙率は20\%である.

\section{（1）透水実験}

アスファルト混合物の透水係数 $k(\mathrm{~m} / \mathrm{s})$ は, 図-2に示 寸実験装置を用いて求めた。ただし，舗装上部にある降 雨シミュレーターを使用しなかったために図中の破線で 示した水面形とは異なり, 水深は上流端（左側）から下 流端（右側）に向かって単調减少する. 実験に用いた排 水性アスファルト混合物は, 底部および主流と平行す る2つの側面を遮水し，それ以外の側面（上流端と下流 端）および上面を開放した。 実験では，排水性アスファ ルト混合物内部の水位を一定に保つために，上流端と下 流端に2.1 mm と1.1 mm の堰をそれぞれ設置した. 排水 量は, 最小目盛0.1 g の電子重量計を用いて測定された. $k$ の值は Dupuit の近似に従うとして次式で与えられる.

$$
k=\frac{2 q L}{\left(h_{1}{ }^{2}-h_{2}{ }^{2}\right)}
$$

ここに, $q$ : 単位幅あたりの排水量 $\left(\mathrm{m}^{2} / \mathrm{s}\right), h_{1}$ および $h_{2}$ : 上流端 $(x=0)$ および下流端 $(x=L)$ の水深 $(\mathrm{m})$ および $L$ : 上流端から下流端までの距離（m) である. なお，本実験の水面勾配は1/30であり，Dupuit の近似の 


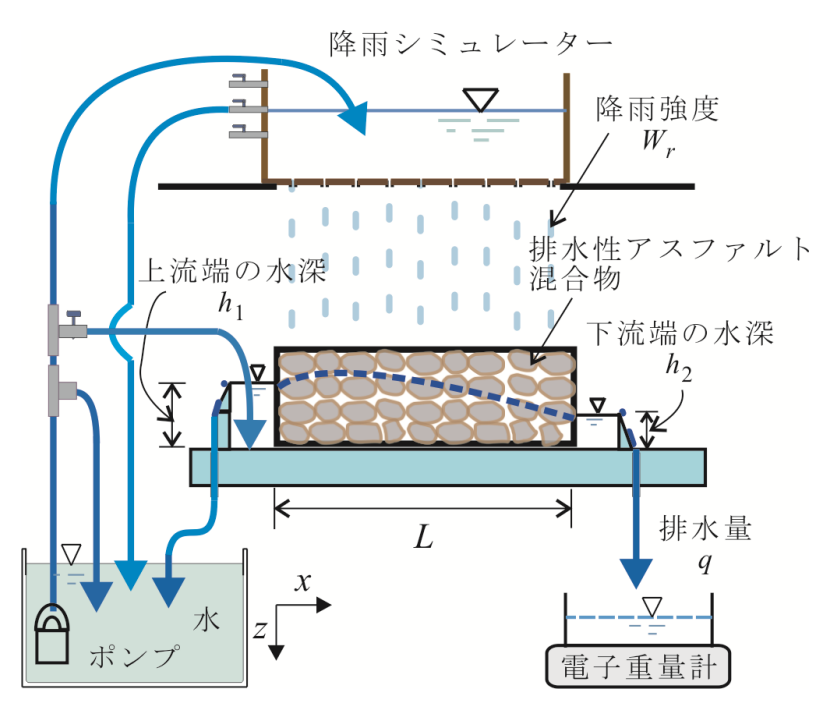

図-2＼cjkstart透水実験および降雨透水実験の装置

適用範囲にある ${ }^{11)}$. また，本実験のレイノルズ数（代表 長さ：平均粒径，代表速度 : 浸透流速）は10～20の範囲 にあり，ダルシー則が使えるものと見なした。

\section{（2）鉛直浸透実験}

図-3は，鉛直浸透実験の装置である，同装置は，上面 と底面のみが開放された排水性アスファルト混合物（側 面はすべて不透水板で遮断），降雨シミュレーター，排 水性アスファルト混合物の質量と排水性アスファルト混 合物を浸透通過した雨水の質量をそれぞれ測定する2つ の電子重量計（最小目盛0.1 g) で構成される. 降雨シ ミュレーターは, 雨水タンクの水位を常に一定に保ち, タンク底部に取り付けた複数の針から点滴で水を落下さ せる装置である。

実験では，電子重量計の自動計測を開始後，降雨シ ミュレーターを稼働させ，一定強度の雨水を排水性アス ファルト混合物上面に滴下させた．本実験に用いた電子 重量計の計測間隔は全て1 秒である. 排水性アスファル 卜混合物上面における雨水の浸透開始時刻および排水性 アスファルト混合物底面における雨水の排水開始時刻は， 排水性アスファルト混合物の質量が増加し始める時刻, および排水性アスファルト混合物下方にある貯水槽の質 量が増加し始める時刻とした. 前者の質量変化は図中の 下側の電子重量計により，後者のそれは上側の電子重量 計により，それぞれ独立して求められる。この2つの重 量変化開始時刻の差を浸透通過時間 $t_{p}(\mathrm{~s})$ とした.

実験では，降雨強度 $W_{r}(\mathrm{~mm} / \mathrm{h})$ および排水性アス ファルト混合物内部の水分状態が鉛直浸透速度 $U_{w}$

（m/s）に及ぼす影響を調べるために， $W_{r}$ は10〜90 $\mathrm{mm} / \mathrm{h}$ の範囲で6ケース, 排水性アスファルト混合物の初 期水分状態は乾燥と湿潤の2ケースとした。ここで湿潤 とは，排水性アスファルト混合物を冠水させた後に一日 放置し，重力水を排水性アスファルト混合物内から除去

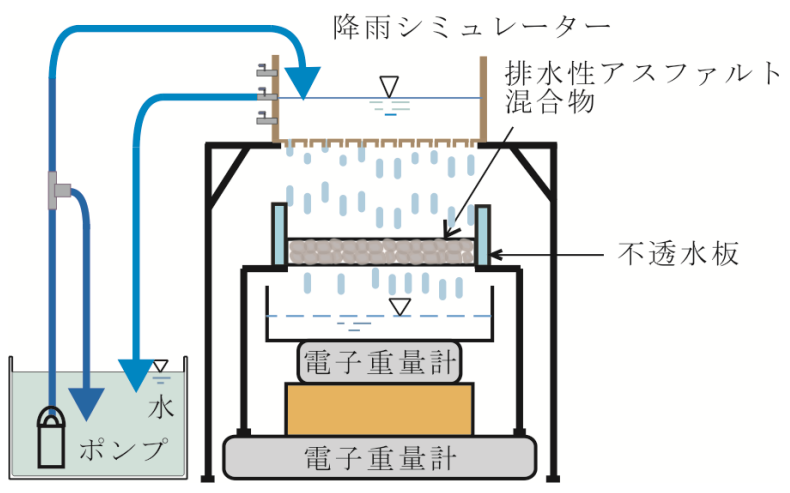

図-3 鉛直浸透実験の装置

した状態とする.

\section{（3）降雨透水実験}

式(1)から得られる $k$ の妥当性を検証するために，図-2 に示す透水実験装置（降雨シミュレーターを装着）を用 いた.（1）の透水実験と違って，排水性アスファルト混 合物上面に滴下された雨水は，上・下流端から排水され る. 排水量は下流側のみ電子重量計によって測定した. 実験は，排水量が平衡状態になるまで行われ，実験条件

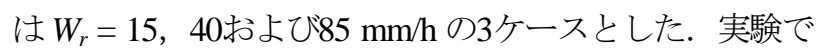
の $W_{r}$ の再現性は高いので, 予備実験を行い， $W_{r}$ は排水 性アスファルト混合物の上にトレイを設置し，滴下時間 とトレイ内貯水量を測定し求めた.

\section{（4）熱 - 水分移動実験}

\section{a）実験装置}

図-4は，熱・水分移動実験の装置である。本実験では 舗装表層に厚さ30 mm の排水性アスファルト混合物，基 層として厚さ70 mm のシリカコンクリートおよび床版と して厚さ40 mm の普通コンクリートで構成される供試体 を橋梁道路に模して用いた。 基層には HEP を埋設して おり，その直径は15 mm，HEP 間のピッチは100 mm お よび被り厚は82.5 mm である. 供試体の上面および底面 は大気と接し，供試体の側面は熱損失を抑制するために $50 \mathrm{~mm}$ 厚の断熱材で覆った。供試体の中央（HEP の中 間）には，鉛直方向の温度分布 $T(z)$ を測定するために13 本の熱電対を埋設した。 また，排水性アスファルト混合 物底面の下流端下部には, 図-4の拡大図に示されるよう に2本の熱電対を設置した，その熱電対の1つは骨材表面 $T_{a g}\left({ }^{\circ} \mathrm{C}\right)$ を測定する. もう一つは，排水性アスファル 卜混合物直下流の排水温度 $T_{\text {wout }}\left({ }^{\circ} \mathrm{C}\right)$ を測定する. その 他，室内温度を温湿度計で，排水性アスファルト混合物 上面および床版下面に入射する長波放射熱フラックスを 放射収支計で，それぞれ測定した。排水量は0.1g 読みの 電子重量計で求めた。これらの計測データは，データロ ガーによって1秒間隔で自動記録された。 


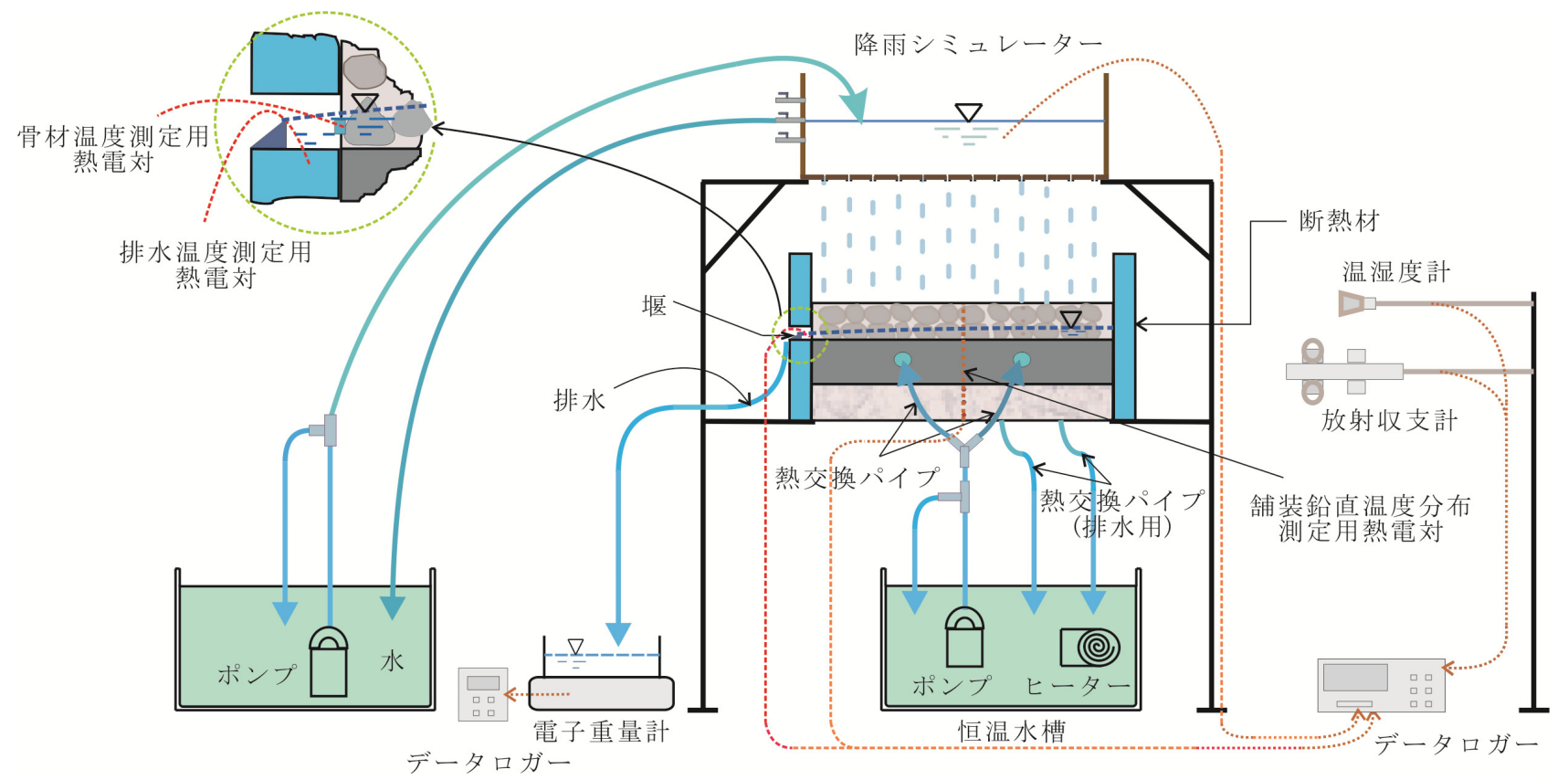

図-4 熱・水分移動実験の装置

\section{b）実験手順}

実験手順は，以下のとおりである。(i)供試体を温度制 御された実験室に放置し，実験開始時の供試体を室内と 同じ温度にする，(ii)水中ポンプを用いて熱交換流体（温 水）を HEP に送る，(iii)供試体の $T(\mathrm{z})$ が平衡状態に達し た後，降雨シミュレーターを稼動させ，供試体上面に雨 水を与える, (iv)T(z)が定常になった時点で降雨シミュ レーターを停止し，実験を終了する。

\section{c）実験条件}

室内温度は $5^{\circ} \mathrm{C}$, 熱交換流体の温度は $30^{\circ} \mathrm{C}$, その流量 は0.6 L/min, 降雨の温度は $5^{\circ} \mathrm{C}$ (室内温度と同じ）, そ の強度 $W_{r}$ は15，40および85 mm/h の3ケースとした.

\section{4. 実験の結果}

\section{（1）透水および降雨透水実験}

式(1)より求めた排水性アスファルト混合物の透水係数 $k$ の值は, $0.075 \mathrm{~m} / \mathrm{s}$ であった. この $k$ の值の再検証およ び啇用範囲を明らかにするために，降雨シミュレーター を取り付けた図一2の実験装置を用いて，下流端からの排 水量について計算結果と実験結果を比較した， $W_{r}$ は15 から $85 \mathrm{~mm} / \mathrm{h}$ の間で6種類変化させた.

単位幅当りの排水量 $q$ は次式で計算される.

$$
q=\frac{k}{2 L}\left(h_{1}^{2}-h_{2}{ }^{2}\right)+\frac{W_{r} L}{2}
$$

結果を図-5に示寸．縦軸は式(2)により計算されたqの 值を，横軸は $q$ の測定值をそれぞれ表す．両者は45度の 傾きを持つ直線関係にあり, 少なくとも上記の降雨強度 の範囲において $k$ の值は $0.075 \mathrm{~m} / \mathrm{s}$ となる.

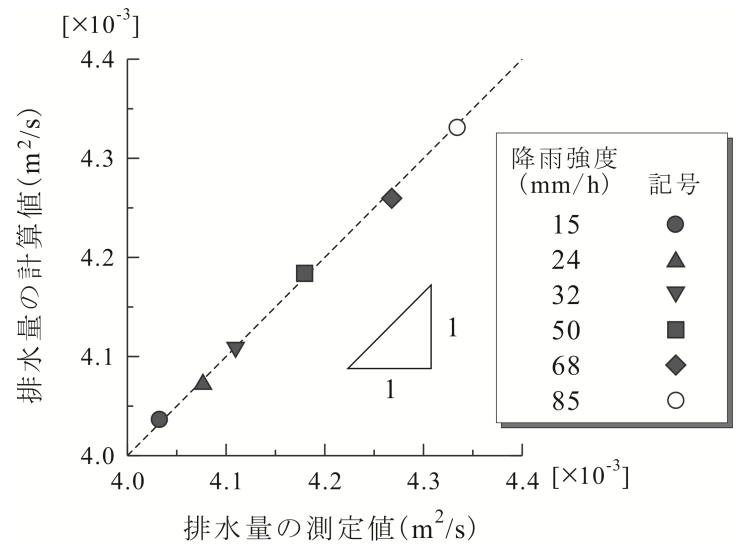

図-5 排水量の計算値と測定値の比較

\section{（2）鉛直浸透実験}

図一は，乾燥状態と湿潤状態における $W_{r}$ と $U_{w}$ の関係 を示す. $U_{w}$ は, 以下の式によって求めた.

$$
U_{w}=D_{p} / t_{p}
$$

ここに， $D_{p}$ : 排水性アスファルト混合物の厚さ $(\mathrm{m})$ お よび $t_{p}$ : 3. (2) に記したように雨水が排水性アスファル 卜混合物内の通過に要する時間（s）である.

$U_{w}$ は $W_{r}$ の増加とともに対数的に増大し, 同じ $W_{r}$ で は乾燥状態より湿潤状態で大きい。この理由として, 乾 燥状態では雨水が骨材に浸透しながら下方へ移動するが, 湿潤状態では骨材浸透がないために雨水の下方移動が早 まったことが考えられる，この関係は，式(4)および(5) で表現される.

$$
\begin{aligned}
& \text { 乾燥 : } \quad U_{w d}=0.0016 \ln \left(W_{r}\right)-0.0037 \\
& \text { 湿潤 : } \quad U_{w w}=0.0024 \ln \left(W_{r}\right)-0.0047
\end{aligned}
$$




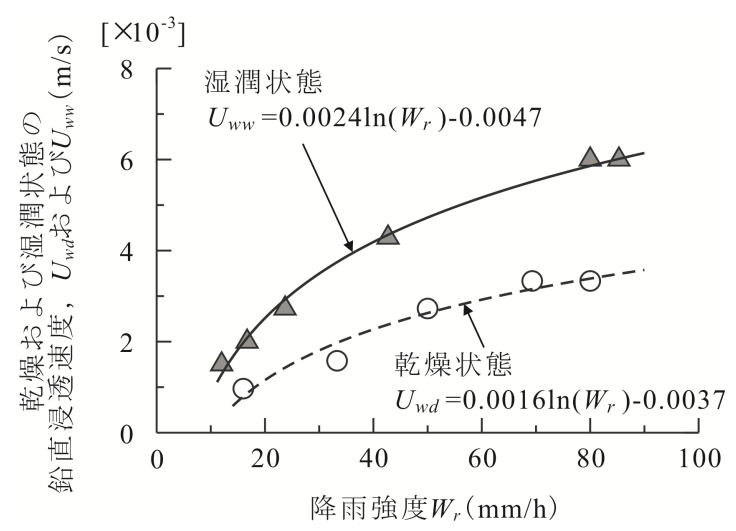

図-6 降雨強度と鉛直浸透速度の関係

ここに，添え字 $d$ および $w$ は乾燥状態および湿潤状態 をそれぞれ意味する，以上より， $U_{w}$ は舗装の水分状態 に依存するとともに， $W_{r}$ の100倍以上大きいことが分 かった. この $U_{w}$ と $W_{r}$ の関係を知ることによって， $W_{r}$ を熱・水分移動解析の境界条件に組み込み込むことが可 能になった.

\section{（3）熱・物質移動実験}

\section{a）供試体の鉛直温度分布}

図-7 (a) 〜 (c) は，実験期間にわたる $T(\mathrm{z})$ の時間変化で

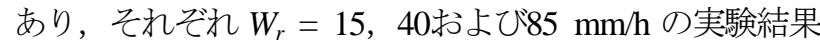
を示す．図中の凡例に示す $0 \mathrm{~h} ， 1 \mathrm{~h} ， 3 \mathrm{~h} ， 9 \mathrm{~h}$ および $12 \mathrm{~h}$ は，実験開始時，実験開始から1時間，3時間，9時間お よび12時間後の $T(z)$ である。また， $1 \mathrm{hR}$ および6 hR は降 雨開始から1時間および6時間後の $T(z)$ をそれぞれ示寸.

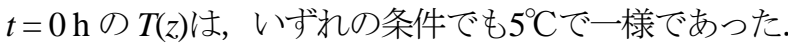
実験開始後, HEP に約 $30^{\circ} \mathrm{C}$ 熱交換流体を通水させた ことで，T(z)は時間とともに供試体全体にわたり上昇し， $t=12 \mathrm{~h}$ で温度平衡状態となった. $t=6 \mathrm{hR}$ の排水性アス ファルト混合物表層の温度， $T(z=-5 \mathrm{~mm})$ に着目寸ると， 図-7 (a) の $W_{r}=15 \mathrm{~mm} / \mathrm{h}$ では降雨によって $5^{\circ} \mathrm{C}$ 程度の温 度低下が認められる．図-7(b)および(c)を観ると， $W_{r}=$ $40 \mathrm{~mm} / \mathrm{h}$ で約 $8^{\circ} \mathrm{C}, 85 \mathrm{~mm} / \mathrm{h}$ で約 $9^{\circ} \mathrm{C}$ 温度低下が生じた. また，供試体底面付近でも温度低下が認められ，降雨浸 透の熱的影響は全域に及ぶが，供試体温度は HEP から の熱供給を受けて周囲気温よりも高い状態で平衡になる ことが分かった．加えて，供試体底面から周囲空気への 熱移動（熱損失）が容認できた.

以上より，HRHS-DP の凍結防止・融雪性能に及ぼす 降雨浸透の影響は，降雨強度が大きいほど無視できない ことが明確になった。

\section{b）排水性アスファルト混合物の下流端下部における 骨材温度および排水温度}

図-8は, $W_{r}=85 \mathrm{~mm} / \mathrm{h}$ での排水性アスファルト混合物 の下流端下部における骨材温度 $T_{a g}\left({ }^{\circ} \mathrm{C}\right)$ および排水温 度 $T_{\text {wout }}\left({ }^{\circ} \mathrm{C}\right)$ の経時変化である. 実験開始時の $T_{a q}$ は

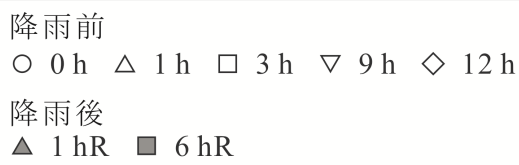

温度 $T\left({ }^{\circ} \mathrm{C}\right)$

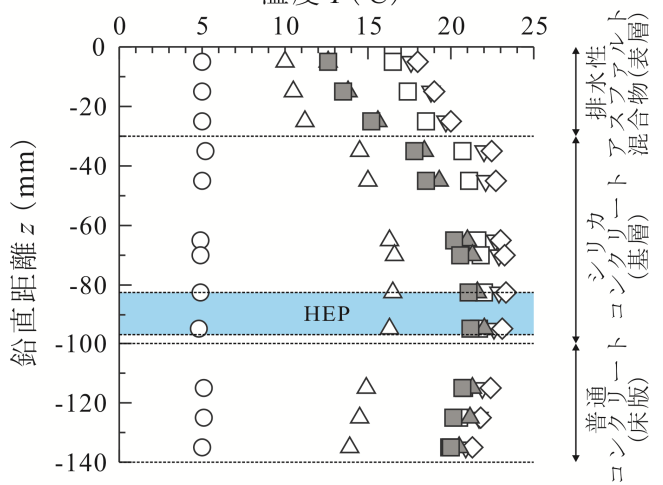

（a）降雨強度 $=15 \mathrm{~mm} / \mathrm{h}$

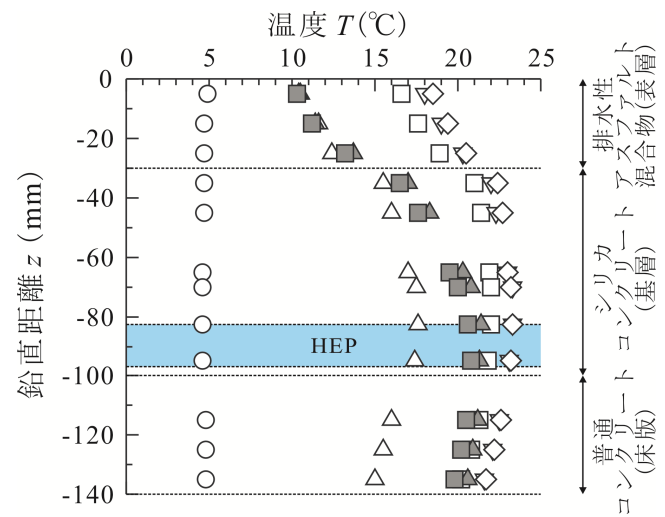

(b) 降雨強度 $=40 \mathrm{~mm} / \mathrm{h}$

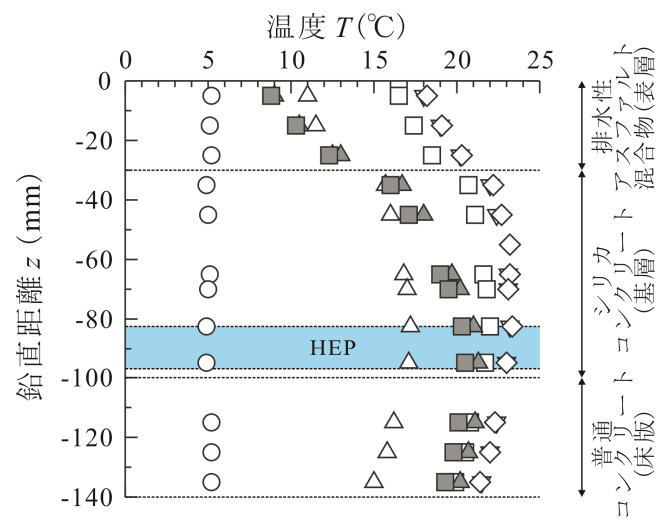

（c） 降雨強度 $=85 \mathrm{~mm} / \mathrm{h}$

図-7 供試体の鉛直温度分布の時間変化

$5.2^{\circ} \mathrm{C}$ であったＨEP からの熱供給は，実験開始より2, 3時間に亘る $T_{a g}$ の急激な上昇を引き起こし, 約5時間後 に $T_{a g}$ は $17.9^{\circ} \mathrm{C} て ゙$ 定常状態となった. 降雨開始後, 約 $5.1^{\circ} \mathrm{C}$ 雨水の浸透に起因して, $T_{a g}$ は $10.1^{\circ} \mathrm{C}$ に低下した. 一方， $T_{\text {wout }}$ は降雨開始直後に $7.8^{\circ} \mathrm{C}$ となった後は, 約 $6^{\circ} \mathrm{C}$ を推移した. 温度平衡状態の $T_{a g}$ は $T_{\text {wout }}$ より $4^{\circ} \mathrm{C}$ 程度高 い. この事を排水性アスファルト混合物の熱・水分移動 


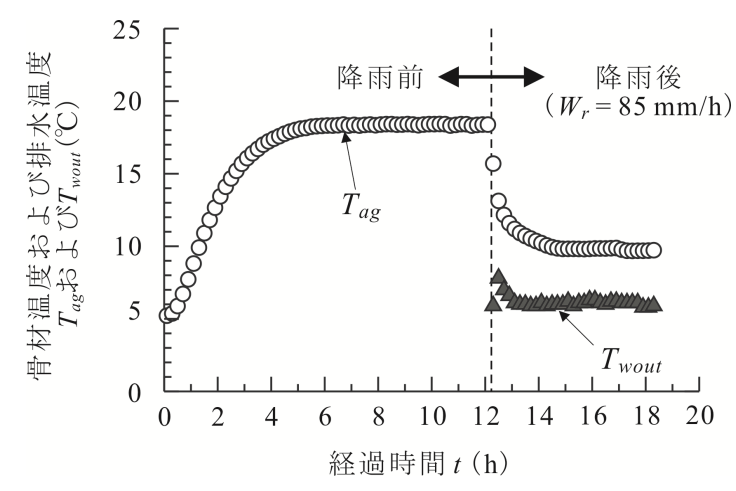

図-8 排水性舗装の下流端下部における骨材温度および排水 温度の時間変化

理論では浸透水と骨材を一体として取り扱うことができ ない，すなわち排水性アスファルト混合物内部では骨 材-浸透水-空気間の熱移動理論の構築が不可欠であるこ とが明らかになった。

以下に，降雨が HRHS-DP の凍䋨方止・融雪性能に及 ぼす熱的影響を定量的に考察する。ここでは，凍結防 止・融雪熱フラックス（舗装表面の伝導熱フラックス） $Q_{c}\left(\mathrm{~W} / \mathrm{m}^{2}\right)$ に対する降雨によって舗装から奪われる熱 フラックス (降雨損失熱フラックス) $Q_{r}\left(\mathrm{~W} / \mathrm{m}^{2}\right)$ の比 $R_{l}$ を評価する. $R_{l}$ は次式で求められる.

$$
R_{l}=\frac{Q_{r}}{Q_{c}}=\frac{(\rho c)_{w} W_{r}\left(T_{\text {wout }}-T_{\text {rain }}\right)}{-\lambda_{p}\left(\frac{\Delta T}{\Delta z}\right)_{z=0}}
$$

ここに, $(\rho c)_{w}$ : 水の体積熱容量 $\left(\mathrm{J} / \mathrm{m}^{3} \mathrm{~K}\right), T_{\text {rain }}$ : 降雨温 度 $\left({ }^{\circ} \mathrm{C}\right)$ および $\lambda_{p}$ : 不飽和状態における排水性アスファ ルト混合物の熱伝導率 $(=0.95 \mathrm{~W} / \mathrm{mK})^{12)}$ である. なお, $z=0 \mathrm{~mm}$ における $\Delta T / \Delta z$ は図-7 (c) の $z=-5 \mathrm{~mm}$ と $-25 \mathrm{~mm}$ との間の $\Delta T / \Delta z$ で近似した. その結果, 温度平衡状態 $(t$ $=6 \mathrm{hR})$ において $Q_{c}=166 \mathrm{~W} / \mathrm{m}^{2}$ および $Q_{r}=108 \mathrm{~W} / \mathrm{m}^{2}$ と なり, $R_{l}=0.66$ となった.

\section{5. おわりに}

温水循環式加温システム（HRHS）を組み込んだ排水 性舗装橋梁道路の熱・水分移動特性を明らかにするため に，透水実験および降雨シミュレーターを用いた鉛直浸 透・降雨浸透実験に加えて熱・水分移動実験を行った. 得られた主な知見は以下の通りである.

（1）透水実験および降雨浸透実験方法と Dupuit の近似 の組み合わせは，排水性アスファルト混合物の透水 係数 $k$ を求めること, および $k$ に対する降雨強度の 適用範囲の評価に有効である.

（2）鉛直浸透速度 $U_{w}$ は降雨強度 $W_{r}$ の100倍以上大きく，
同じ $W_{r}$ でも乾燥舗装よりも湿潤舗装で $U_{w}$ は大き くなる.

(3) 降雨開始後の温度平衡状態における降雨損失熱つ ラックスは凍結防止・融雪熱フラックスの $66 \%$ に相 当し, HRHS-DP 中の熱移動に対して降雨浸透の影 響は無視できない。

（4）HRHS-DP の骨材温度と浸透水温度との差は有意で あることから，排水性アスファルト混合物内部では 浸透水々骨材に対する熱移動の理論化が必要になる. 以上，本実験によって HRHS-DP の熱・水分移動理論 構築の方向性を示寸こと, およびその検証データを得る ことができたので，今後は HRHS-DP における骨材-浸 透水-空気間の伝熱理論の構築を目指寸.

\section{参考文献}

1) 石田樹・田高淳 : 国際摩擦指標（IFI）による舗装路面のテ クスチャとすべり摩擦の評価, 寒地土木研究所月報, No. 640, pp. 36-39, 2006.

2）日本道路協会舗装委員会環境・再生利用小委員会 : 排水性 舗装発生材の再生利用確立に向けた直轄国道試験施工の中 間報告, 日本道路協会, p. 1, 2005.

3) 福原輝幸: 道路・歩道における消・融雪技術の現状と課題, 日本雪工学会誌，Vol. 24， No. 4, pp. 67-70, 2008.

4）杉村佳昭 : 珪石骨材を用いた高熱伝導型排水性舗装（低騒 音）舗装に関する研究，福井県・雪対策建設技術研究所年 報「地域技術」，Vol. 15，pp. 13-18， 2002.

5) 早坂保則：高規格幹線道路における排水性舗装の冬期路面 管理 一一般国道39号美幌町美幌バイパスにおける調査-, 北海道開発士木研究所月報, Vol. 581, pp. 35-40, 2001.

6) 日本道路公団保全交通部：高速道路の冬期道路管理におけ る取組み，道路行政セミナー（2000. 12），pp. 38-43，2000.

7) 久保和幸・寺田剛: 排水性舗装の冬期路面管理に関寸る研 究, 土木研究所成果報告書, No. 24, pp. 1-10, 2009.

8) PIARC Technical Committee 2.4 Winter Maintenance: Snow and ice databook, 2014.

9）藤森章記 - 佐野正典 : 二層構造式排水性舗装の融雪機能に 関する検討, 近畿大学理工学部研究報告, No. 38, pp. 8791, 2002.

10）山口正敏・横山孝男・安彦宏人・堀野義人・沼澤喜一: 排 水性舖装体内放熱管による融雪特性一その 1 -, 寒地技術 論文・報告集，Vol. 22，pp. 244-247， 2006.

11) 佐藤邦明・竹下貞雄 : 不圧地下水流におけるDupuitの公式 の原点，土と基礎，土質工学会誌，Vol. 39，No.12，pp. 4952, 1991.

12) 田中貴子・藤本明宏・福原輝幸 : 排水性舗装の熱伝導率の 水分依存性, 雪水研究大会（2010・仙台），p. 41，2010.

(2015. 9. 30受付) 